\begin{tabular}{l} 
RCCS \\
\hline Annual Review
\end{tabular}

\section{RCCS Annual Review}

A selection from the Portuguese journal Revista Crítica de Ciências Sociais

$1 \mid 2009$

Issue no. 1

\title{
Territories Named Desire: From the Breadth of Concepts to the Containment of Experience
}

\section{Daniel Francisco}

Translator: Monica Varese

\section{(2) OpenEdition}

\section{Journals}

Electronic version

URL: http://journals.openedition.org/rccsar/138

DOI: $10.4000 /$ rccsar. 138

ISSN: 1647-3175

Publisher

Centro de Estudos Sociais da Universidade de Coimbra

\section{ELECTRONIC REFERENCE}

Daniel Francisco, « Territories Named Desire: From the Breadth of Concepts to the Containment of Experience », RCCS Annual Review [Online], 1 | 2009, Online since 01 September 2009, connection on 19 April 2019. URL : http://journals.openedition.org/ rccsar/138; DOI : 10.4000/rccsar.138 


\section{Daniel Francisco}

School of Economics and Centre for Social Studies, University of Coimbra, Portugal

\section{Territories Named Desire: From the Breadth of Concepts to the Containment of Experience $^{*}$}

Several reasons have contributed to focusing the attention of the social sciences on the dynamics linked to territories, given the relevance that the themes of power, development and social cohesion have taken on in those dynamics. This article addresses the way in which territorial contexts have actually embraced recent conceptions of power and the State, discussing the extent to which this expresses a new way of doing politics or, on the contrary, whether customary and insufficiently innovative modalities of action continue to be reproduced at local level.

Keywords: Territory; governance; local government; public policies.

\section{Introduction}

Over the past decades, the importance attached by the social sciences to territorial scenarios, i.e. infra-national spaces, can be explained, among other factors, by the circumstances which have weakened, at least since the 1960s, the predominance of "central" authorities and functions over the "periphery." By designing new forms of political organisation and a new face for the State, such circumstances led the centre-periphery scheme to lose the relevance that had previously been attached to it, as the "centre," its jurisdiction and its elites experienced a reduction in their authority over the periphery.

These were years of decisive change. They saw the emergence of the crisis of the State and the waning of Fordism, the logics of "detotalisation" (Bayart, 1985) ${ }^{1}$ and the decline of traditional decision-making pyramids, "networking" and the superimposing of "governance" practices on governmental authority over social agents and sectors. In addition, the contradictory flows of globalisation and of "flexible" capitalism changed the socio-economic profile of our societies and gave rise to considerable revision of the principles of social analysis. Versions of "structuration" (Giddens), of methodological individualism and, in the area of political science, of sociological neo-institutionalism (Hall and Taylor, 1997), manifest in multiple approaches and concepts like "networks," "configuration," "social capital" or the "game of actors," relativised previous functionalist and holistic views. The goal was to draw

\footnotetext{
* An extended version of this paper was published in RCCS 77 (June 2007).

${ }^{1}$ These are civil society social and political practices that lead it to withdraw the social sphere from domination by the State. For this author, "civil society's advances" create a complex and ambivalent dynamic between the
} 
methodologies closer to individuals' beliefs, representations, symbols and values, but also to capture their rationality "in action," in the pragmatic appropriation of circumstances. This conferred unprecedented importance on territories, seen as privileged sites for culture formation and management of interests, for mobilising networks and carrying out projects, for strategic action and institutional regulation - in other words, for confrontation and compromise between distinct versions of power and development.

Interest then focused on the way historical-geographical conditions produce singularities and render phenomena complex. ${ }^{2}$ Systemic determinisms, functional imperatives, abstract precepts for evaluation of facts, all these lost significance. They were replaced by attention to the lived, experienced and imagined reality, where individuals make sense of experience and reconfigure it in more formal or universal ways. In showing how each society makes its own construction of the economic and the political, emphasis was given to the specific configurations of actors, norms, institutions and leaders emerging from the territories. The idea is that, quite as important as the structures and rationalities that rule over the spaces, are the worlds experienced, biographical trajectories, collective memory, relational networks, the institutions and leaders rooted in them, i.e. the concrete experiences and worlds which emerge whenever we see human constructs in their specificity. ${ }^{3}$

\section{The territory and the transformations of the State}

To understand the prominence achieved by territorial logics, we must turn to the changes that have affected public action in recent decades. There was a time when the State administrated society and the territory based on an expansive industrial economy, on the integration of peripheral elites into the political system, and on intermediaries holding a monopoly over representation at national or sectoral level (political parties, trade unions, business confederations, churches). However, especially after the sixties, the socio-territorial equilibrium promoted by the centre, as well as the conducting of local interests in

\footnotetext{
State and society, which discards the dualist, dichotomic or binary view of these realities, usually linked to the idea of the control of civil society by the State.

${ }^{2}$ The relation between centre and periphery, in particular, was addressed from the viewpoint of the diverse list of elements - economic, political, cultural, psychological - which interact in its structuring and make it pluridimensional, shaped by the particularities of each situation.

${ }^{3}$ The "local" expression of facts has been related to a specific cartography, that of contextual variations. This means that it is in localised and specific universes that actors acquire a pragmatic sense of the economic, legal or political fields, "playing with the variation of the scales of space and time, and freeing themselves from the constraints of pre-established models" (Cefaï, 2001: 16).
} 
accordance with government priorities and the corporative systems organised by the State, all these proved ineffectual and lost legitimacy. A sort of "post-dirigisme" settled in, disturbing the hierarchical integration of social actors and the action of the State in respect of society's problems and dynamics.

In practice, the crisis of the Keynesian programme and the collapse of public finances restricted State intervention. Structural adjustment programmes in developing countries and the demands of budget containment in Europe, with repercussions on the difficulty experienced by governments in ensuring full employment in different regions, left many territories without support and dependent on favourable insertion into global markets. ${ }^{4}$ The pressures of a competitive economy based on innovation and knowledge, combined with the State's difficulties in maintaining mechanisms for correcting territorial asymmetries, began to shape the future of cities and regions, introducing the idea of interterritorial competition.

The paradigm of local development replaced centralised planning. Development from "below" emphasised the functionalities and endogenous resources of the territories. The role of conventions and institutions, both public and private, as well as the importance of networks of territorial actors were used to explain the degree of success with which the economies of countries and regions participated in the global flows. ${ }^{5}$ The geography of "costs" and "stocks of factors" gave way to that of "organisations" and quality of institutions (Veltz, 2002: 12), in a world economy where competition now involved, not simply products, but ways of organising society and social systems (Pecqueur, 2000).

Of course, the profusion of analyses on "territorial" issues gave rise to multiple theories that made the territory as a category problematic and fluid. Viewed either as history and culture rooted in a space, or as a mere response to "external" opportunities and constraints (in the sense of being constructed by networks which activate territorial responses at any given moment, as a result of specific strategies aimed at certain interlocutors), the territory can also be viewed as the jurisdictional framework of a concrete body (municipalities,

\footnotetext{
${ }^{4}$ The times when the State, by negotiating with industrial groups, piloted jobs towards distressed areas, thus balancing territorial development, are over: "[T]he crisis had an effect on that. And the growth that ensued, diffuse and based primarily on service sector jobs, does not provide the same kind of support to public policies" (Veltz, 2002: 10).

${ }^{5}$ The combination of cultural and institutional factors, of collective memory and political regulations which explain performances at territorial level, has given rise to assessments that view territories, for instance, as
} 
administrative regions, urban or metropolitan communities), the space of functional articulation of certain logics and powers (industrial districts, metropolitan areas), or simply as floating, unstable, virtual matter. The fact is that the "new political economy" and economic sociology have shown that economies emerged from the crisis of the Keynesian models relying on institutional and cultural factors of a local and national nature. This gave analytical substance to the territory - as a space of decision-making and production, culture and the market, networks and institutions. Although highlighting the multiple paths towards development, these approaches present it essentially as the result of territorially situated dynamics. This means that development reveals a deep "contextual dependence," being anchored in the social, political and cultural realities of certain spaces. Development processes will thus occur in spaces where some collective efficacy emerges, stemming from primarily endogenous and shared features. ${ }^{6}$

\subsection{The emergence of "governance"}

Interest in "territory" stems also from the changes that have recently reconfigured the State and national societies. In a sense, demands from local governments to administrate larger portions of life in territories are related to the differentiating territorialisation processes occurring in the economy and corresponding socio-political changes. Among these, I would single out the attacks on centralised management and the governability deficits ascribed to complex and fragmented social systems (Luhmann, 1999); the crisis in the democratic representation of citizens and in political mediation in general; the distrust of ideologies, politicians and central apparatuses of social regulation, viewed as remote, sluggish and heavy, held captive by paralysing bureaucracies and networks of interests that manipulate them; anaemic social bonds and the erosion of institutional protection of citizenship (Dubet, 2002); and the increase in individualism and in "free rider" attitudes (Olson) displayed by

spaces of intermediation of multiple trajectories, feeding on "a multiplicity of genes that will lead (or not) to a given dynamic, to cohesion, to self-awareness and empowerment" (Lacour, 1996: 35).

${ }^{6}$ In this sense, the materialisation of activities in space, the economic landscape, may be "the foremost form of regulation" (Benko and Lipietz, 1994: 247). But, more than that, the territory may be a genealogical source of processes, notably for coordinating actors, who find in it vocabularies, logics, the power and the tools with which to pursue goals and realise intentions (Reis, 2006). Relational behaviours and cognitive practices triggered by proximity must therefore be deemed decisive in generating processes. And the territory is crucial, not simply for economic behaviour, but also for "the matrix of relations that defines the morphology of power in contemporary societies" (ibid.: 7). 
citizens towards public policies. All this led to a crisis of the State and of nations as we know them.

These factors, acting on public sectors and their policies, have made for special turbulence over the past decades. They convey not just the disappearance of the post-war world of clear orientations, ${ }^{7}$ depriving States of their capacity to pilot society, but also the intensification of failures in government itself (Mayntz, 1993), which have amplified public administrations' difficulties in regulating and enforcing their legitimacy. ${ }^{8}$ In practice, as public action displayed successive failings, the pressure to "liberate" society's capacity for self-regulation grew, expressing the resistance of many sectors vis-à-vis the State. Groups and networks interested in public policies made their presence felt, undoing State monopolies and advocating private management of the public sphere.

To facilitate this, the principles of capitalist microeconomics are transferred to the State, with the new public management promoting a "minimal state," obeying criteria of competitiveness and guided by self-organising networks (Rhodes, 1997). The migration of business management into the State means the takeover of public action by corporate governance rules. ${ }^{9}$ This is passed off as modernisation, when very often it is nothing but the mere transformation of public administration bodies into market entities. ${ }^{10}$ In the end, "rational choice" extends into every domain, toning down, notably, the differences between the public and the private.

\footnotetext{
${ }^{7}$ Supervision of macro-economic equilibria, development planning, organising societal interaction.

${ }^{8}$ For Mayntz (1993: 13), failures in public authority can be grouped into four regulation problems: the inability to enforce regulation (the implementation problem) when faced with the refusal of social groups, not infrequently coupled with that of bureaucracy itself, to acknowledge the legitimacy of such regulation (the motivation problem), inadequate reflection on or assessment of the means/ends relation (the issue of ill thought-out causal relations, the knowledge problem), lack of (legal) competence and of instruments for governing (the institutional issue, the governability problem).

${ }_{9}^{9}$ Robust financial control of management, inter-sector, inter-network and inter-public service competition for "clients," value for money in partnerships or competition with the market (aiming at profit, rather than political-ideological goals), an end to hierarchical chains and procedures, pragmatic expedients in decentralised cooperation in this or that project, etc.

${ }^{10}$ Throughout Europe, similar mechanisms for administrative reform have been put in place. Aiming at reducing the weight of the State, business management has been introduced into public service provision and autonomous executive bodies into ministries; performance indicators, competition and accountability have been established in traditional bureaucracies with a view to making them more professional, mobile and controlled by independent authorities, such as Quangos in the UK. The idea was to privatise tasks and liberalise broad areas of public sectors - going as far as to suspend many of the Welfare State's obligations - imbuing the administrative landscape with the new public management. In the end, not only are the frontiers between the public and the private drained of meaning, but the sense of the State as "supreme value of protection" and guarantor of individuals' ways of life, by now virtually gone in Western Europe (Inglehart, 1993), will give way to the feeling of void inherent in an "État-creux" [hollowed-out State] (Leca, 1994, picking up Guy Peters's term).
} 


\subsection{Government and "governance"}

A heterogeneous cluster of groups and forces, often linked to transnational networks, has appeared in the field, posing serious regulation problems to public administrations. Demanding both satisfaction of their interests by public policies and unfettered powers to determine relations with others, they are replacing the theoretically integrated space of the State and the nation by an "institutional polyarchy characterised by the confrontation of heterogeneous and unpredictable powers, which are difficult to hierarchise" (Duran and Thoenig, 1996: 580). This is taking place in a political arena which is becoming "undifferentiated under the pressure and multiplication of interest groups whose action interferes with that of political authorities, to the extent of breaking their monopoly on representation and argumentation" (idem).

These groups' organisational capabilities are related to specialised tools, such as the law and engineering, and to the technicist approach (Santos, 2005: 15) that is now used to assess the legitimacy to act in the public sphere and manage government policies. Removed from the equation is the coercive power of the State, which only appears as a partner "provided that it participates in a non-state capacity, ideally on an equal footing with other partners" (idem). In practice, the State is pressured into permanent negotiation - formal or informal, predictable or chaotic - with the multiple actors which modernisation and social complexity have engendered. By absorbing government functions, the latter have become mentors and agents of public policies, determining their procedures, contents and social effects. Not infrequently wielding the power of veto over decisions, these agents make public authorities act on a more horizontal plane, so as to mobilise them, to draw on their resources or to participate in their networks.

Complex overlaps of actors - involving the State and civil society, politics and administration, centre and periphery - therefore dilute the borders between public and private, decision and implementation, and distinct territorial levels, with talk of "governance" instead of "government." In a situation in which the rule becomes the dispersal of competences required for action, as well as the multiplication of channels and interdependences between different levels of government, institutions, sectors of activity, and agents in general (Kooiman, 1993; Jouve, 1995), there is no unified basis for integrating the logics of actors. Having lost its main attributes and social regulation tools, the State finds 
itself subjected to unpredictable processes of confrontation involving agents and networks which differ greatly among themselves.

For public authority, each step must now be measured, negotiated, respectful of the singularity of situations and admitting interlocutors holding growing levels of organisation, technical qualifications and demands. Governance means that public administration must deal with participants guided by very different rationales, coming from a competitive society and who impose themselves on the State. The stress is on the end of the monopoly enjoyed by government actors in decision-making processes, as hierarchical governing practices are replaced by more horizontal, cooperative and consensual modes of organisation (between public and private, centre and periphery). In these configurations, which draw on the private sector and the most dynamic social groups, no organisation enjoys full autonomy. Even if it wishes to impose a measure of control, it depends on others, in apparatuses in which no one holds all the power, but all have some portion of it - which tends to render decision-making mechanisms opaque and makes accountability problematic (Stoker, 1998). That is to say, public action unfolds in an organisational system which is far from the degree of coherence and completeness we used to associate with the government machinery. The objective, linear and instrumental action of the State is dissolved by the interplay of actors (public, private, associative) which envelops it at every level. Very diverse interests and powers interfere in public options, in a scenario where participants' fragmentation and individualism - in a permanent "rival partners" attitude - is the rule (Gaudin, 1999). With them, public authority has no choice but to negotiate.

Thus, the State is stripped of its role as sole authority, being left with the role of initiator, or instigator (Donzelet and Estèbe, 1994), of networks and partners relevant for public functions. The underlying assumption is that the State does not possess, on its own, the agility and efficiency required for "operational" performances, limiting the impetus of a "liberated" civil society and of the "living" forces in the territories. Hostile to centralised forms of control, the latter give preference to "flexible" project coordination - i.e. conducting dynamics from "below," with no hierarchical and bureaucratic commands holding back the necessary pragmatism. Investing in functional skills and in the virtues of management, they devalue the institutional representation of politics, championing the opening up of the political to the market. The intention is to legitimise those who are in a position to handle public policies according to business criteria, emphasising multipolar 
cooperation and negotiation networks, informal relations and the flexible arrangements of partnerships, especially those which bring together distinct social universes.

Hence the transfer of decision-making to specialised networks, to which the massive instrumentation of public policies has been bringing comfort (Lascoumes and Le Galès, 2005). Mechanisms for control and discipline, calculating and estimating, technical evaluation and codification of "governability" (Foucault) become widespread, entailing not just the "depoliticisation" of government activity - the issues of legitimacy and power are shed in favour of "problem solving" - but also the prominence of networks of experts without whom nothing seems to work. ${ }^{11}$. Comprising "intimates" or "partners" whose status is defined by possession of specific types of knowledge, converging interests or a common, inter-peer past, such networks can be endowed with transparency and internal consistency. That is to say, they can be legible and open to participation from "within," but they tend to prove opaque to the outside, lacking transparency, openness or codification compatible with other sectors, networks, and the public at large (Papadopoulos, 1995). At the end of the spectrum, important decisions may fall under the aegis of technocracies that are impermeable to public scrutiny, following "the tendency to hand over the debate to those who have the reputation of possessing modern skills and know-how" (Gaudin, 1995: 55). More often, decision-making relies only on agents selected because they are specialists or representatives of interests who are legitimised to intervene in public policy. Whatever the case may be, they always reflect the weight of the "local orders" (Friedberg, 1993) established by networks, fragmenting the State and society to such an extent that they can become a major risk for citizenship and for democracy. As Rouban (1999: 2) states, "networks are not necessarily democratic, and more often create communities than they do citizens."

It therefore comes as no surprise that these complex and unstable universes - peopled by competitive agents, and in which the former "certainties structured" by State norms give way to "non-structured uncertainties" (Duran and Thoenig, 1996) in a vaguely organised anarchy - introduce profound deficits in notions of the common good. The "general interest" becomes controversial, as the idea of a broadly encompassing interest loses credibility. Self-organised groups or networks now intervene in the definition of the "general

\footnotetext{
${ }^{11}$ Lorrain (2004: 165) argues that elected officials have given way to experts, just as in the world of business Schumpeterian entrepreneurs have been replaced by Burnham managers.
} 
interest," conditioning deliberations negotiated with them. The result is that between networks and interests, on one side, and normatively oriented institutions, on the other, the space for possibilities, controversies and competition has become magnified. Opportunities for cooperation, convergent views, the integration of goals between the public and the private, the state apparatus and networks, may emerge, as stressed by optimistic versions of "governance." Nevertheless, zones of friction and confrontation are more obvious. Understanding and compromises may appear, but almost always on sectoral issues, under tension and on the brink of stalemate. This means also that state authorities, economic forces and associations become involved in a permanent dispute in which public accountability and legibility tend to blur. ${ }^{12}$ Public policies have come to be based on explanations of the "'communalisation' type, which insist on the fabrication of socially and/or geographically restricted (to certain groups and/or certain territories) compromises, on compromises between levels of management - local, national and international - as well as on agreements achieved through the fabrication of common referents, or, in other words, shared cognitive senses" (Massardier, 2003: 64).

In addition, massive recourse to highly complex technical and legal devices in conducting public life means that power ceases to be in citizens' hands and even those of government officials, to become incorporated into "instruments that operate as technical systems independently of actors" (Lorrain, 2005: 189). This entails a severe restriction of the perspectives of those intervening in the public sphere, producing a loss of meaning and a feeling of "impotence" and discomfort vis-à-vis political activity. In the face of the "autopilots" of specialised fields (political, legal, technical), with their own temporalities and obeying sometimes remote influences, we are not only deprived of an overall view of things, but the great principles of public action (social justice, democracy, the common good) and the personal relation between elected representatives and citizens fade away. Interfering in public policies is left to whoever manages - discreetly and strategically, far from public scrutiny - to condition them even before they see the light of day.

Accordingly, the intention of building more just and coherent societies vanishes, as ongoing changes in the practice of citizenship attest. The favouring of the economic and

\footnotetext{
${ }^{12}$ Anglo-Saxon theory has shown how, in public action, all linearity can be suppressed, with procedures taking on an essentially "incremental" character. This leads to "organised anarchy" (Cohen, March and Olsen, 1972) or to the "disjunctive incrementalism" of "muddling through," i.e. to a governing practice whose sole objective is to reach mutual adjustments between the interacting parties (Lindblom, 1959).
} 
social aspects of citizenship transforms growing strata of the population into producersconsumers of social services, that is, providers-beneficiaries deprived of political citizenship proper (Schnapper, 1994b: 15). The fragmentation of the State into policies and sectors managed on the basis of "expertise" leads therefore to an equally fragmented view of the citizen. This highlights the economically and socially assigned condition of each person - that of consumer of policies manufactured by experts, rather than that of someone integrated in a territory, to be viewed under the prism of his/her capability as regards politics, his/her attachments or identity. ${ }^{13}$.

Finally, the image of the State that emerges is that of an array of forces, organisations or agencies in permanent competition, like a "composite aggregate of heterogeneous elements, each one with its own politics and rationale" (Timsit, 2004: 306). The impression is of a fragmented machine, poorly driven by bureaucratic rigidity and liable to moulding by different interests, less authoritarian and more "negotiated" (Streeck and Schmitter, 1985; Ruivo, 1993), whose parts do not work with a view to a coherent whole. Coordination of State activity does, in fact, appear to be constantly based on negotiations, rivalries and internal alliances (Poggi, 1996: 32), following corporative or lobbying rationales that undermine the notion of a coherent whole. More than the expression of a collective will, the State can perhaps be described as a field of competing forces.

\section{3. "Proximity" and territories as actors}

It may now seem strange to speak of ongoing processes of public action renewal, referring, specifically, to socio-political aspects that are coherently and efficiently organised, involving multi-level participation within a specific socio-institutional framework, with a view to achieving the "common good." However, this is the case when focusing on the importance which "proximity," the "territories," subsidiarity, local partnerships, the delegating of competences "downward," in sum, the philosophy and the range of instruments in the hands of local government, has taken on in Europe over the past decades. This importance cannot be overstated, and all these aspects point clearly to an option for the "local" as a factor in revitalising public life. In other words, the territory has become a new principle in public action and local powers vehicles for reintegrating the particular into the general, or

\footnotetext{
${ }^{13}$ The purpose is to convert the citizen into "the user, supported or excluded, or some such term that fits the consumer or the client of the private sector" (Pongy, 1997: 123-124).
} 
the individual into the collective, in the pressing struggle to keep "together the different parts of the social body" (Lorrain, 2000: 39).

This option has been disseminated by successive instruments which have given it material form and made it irreversible. The purpose of decentralisation is to modernise public action and renew the legitimacy of public authorities. Indeed, this has been the driving force behind many reforms in the European political systems in the past decades, committed as they are to recovering government authority, reconciling citizens with their representatives and rebuilding social ties. The virtues attributed to proximity contexts are expected to bring greater transparency and accountability to public decision-making, as well as greater speed on the part of the ruling class in responding to people's problems, meeting their needs of territorial identification and of a more participatory democracy, open to civil society. ${ }^{14}$

In addition, proximity responds to a European Union mobilised around principles such as subsidiarity and participation, which are at the operational core of its programmes. In this sense, Europe, too, has favoured the movement of "territorialisation of public problems, which cannot be uniformly addressed at central level and whose issues have to be considered and formulated on a case by case basis by proximity actors" (Mabileau, 1997: 357). ${ }^{15}$ This led to the establishment, in several countries, of a more "intergovernmental" framework involving centres and peripheries, placing on a more balanced plane characterised by greater dialogue and mutual respect - relations until then viewed as being simply of a hierarchical nature or of dependence of peripheral agents vis-à-vis central directives. ${ }^{16}$

\footnotetext{
14 "Proximity" has become the magic formula, the totem-word or new fetish of the political world (Lefevbre, 2001). The idea is that, "in order to be effective, certain processes of action presuppose mutual involvement, exchange, coordination, swiftness in management and in mobilising resources, flexibility and adaptation, all of which require relations of proximity (in the physical and geographical senses of the term)" (Lefevbre, 2001: 117-118).

${ }^{15}$ Authors who have addressed "multi-level governance" highlight the structure of opportunities that European construction has opened up for regional and urban power configurations. By broadening their room for action and their range of resources, Europe has converted them into actors in their own right, both at domestic and European level.

${ }^{16}$ Analysis shows that this was never the case. Rather, it reveals the extent to which peripheral "forces" have always been dynamic and creative in the dialectical tension with the centre (Chevallier, 1978; Ruivo, 2000a). Between centre and periphery there have always been communication and exchange circuits which have never been mere channels for the mechanical absorbing of the centre's determinations by the periphery. On the contrary, they respect the exchanges, interactions and interdependent links which make political systems a dynamic construction between centre and periphery.
} 
Thus, if on the one hand the market, individualism and social complexity force the State to draw back, on the other, conditions have been created for intermediate territories, such as cities and regions, to be able to emerge as an alternative stage for integrating actors, organising forces and regulating socio-political realities. ${ }^{17}$ Governability can thus be renewed by drawing on the capacity for reflection and action mobilised by different actors in territories, where interests are more tangible and alternative forms of public action may be promoted. Public-private partnerships, infrastructure management involving technical personnel, politicians and public service beneficiaries, extensive harmonisation of different perspectives and consultation of populations, all this within frames of flexible decisionmaking, appear to be the new ways of "manufacturing" the political discernible in the territories.

To the extent that public and private organisations have, in certain places, gained shape and coherence, forming configurations of actors driven by territorialised programmes, "collective territorial actors" of an urban or regional nature may emerge, together with the redefining of the populations' identities and collective meanings. This occurs in a context in which the European dimension is fundamental, given the recognition of territorial ambitions by the EU (Jeffery, 1997) and its normative influence on member States, pressuring them to adopt a favourable attitude towards subsidiarity and decentralised administration. ${ }^{18}$ Therefore, the networks of actors, the strategies and interests that interfere in public policies, despite their disaggregated, polycentric and even chaotic nature, can become more coordinated in territorial scenarios. The territory will give rise to a new form of constructing the political, superimposing "transversal," "concerted," "cooperative," "co-produced" and "hybrid" modes of organisation over state and professional sector apparatuses. In more diffuse or integrated ways, city and regional government agents will forge modes of strategic action inserted in "project" dynamics, "contract" logics, "public-private partnership," local identities. This will create an alternative to the sectoral, fragmented and technocratic treatment of issues (social exclusion, sustainable development, public

\footnotetext{
${ }^{17}$ As argued by Le Galès (1998: 231), Europe's nation-states have lost part of their ability to regulate and structure society, but other territories have emerged as sites of social and political regulation. These are precisely the infra-national territories - cities and regions - which can regulate interests, groups and institutions.

${ }^{18}$ This type of consideration is based on the premise that the field of possibilities, institutional learning and guiding principles conveyed by the European Union now guide subnational authorities, reinforcing their competences and resources.
} 
transport, cultural activities, etc.): a transversal, global approach, unified by a territorial perimeter which is favourable to cooperation. As Donzelet and Estèbe state, "the territory joins together in concrete terms that which sectorialisation separates in the abstract" (1994: 22-23).

This is why "governance" has been much debated at the local level, at a time when territories appear to be revitalised by "systems of actors who are responsible for a substantial number of public policies and for the production of common tools for the management of the collective" (Duran, 1999: 17). The argument is that progress in decentralisation reforms, on the one hand, and in European construction, on the other, coupled with territorial logics in the economy, has reinforced networks of actors and institutions, leadership structures and strategies at territorial level, and the State must now adjust to this scenario. Because the State has had to resort to contractual procedures with local organisations and authorities, analyses have called attention to these new power articulations, suggesting that an innovative political-administrative architecture is emerging from cities and regions. State authority does not disappear, but rather finds news functions in coordinating the negotiating capabilities of actors in the field (Duran and Thoenig, 1996). The State becomes in fact a crucial mediator in the transition to collective action at the territorial level. It knows that it may be submerged by the dynamics associated with the multiple, fluid and contingent configurations which it helps to create (Saez, 1997). However, not being in a position to resume its erstwhile omnipresent and controlling role, which would mean the failure of cooperation with the actors in "the field," it will have to learn to envision itself as a "State in relation," a system conjoining phenomena, which, involved in social relations, defines itself essentially by how it manages this involvement.

In turn, local spaces, cities or regions will acquire a new prominence by resorting to figures other than elected local representatives in the mediation, definition and implementation of public action, thus reinforcing their respective systems of political organisation. "Civil society," notably, can be called upon to participate in the complex coalitions which, emerging from territories, now deal with the broad range of issues addressed by public policies. 


\subsection{Aspects of local governance}

For all these reasons, political science has attached great importance to the forms of collective action in territories. Notions of "political exchange" (Négrier and Jouve, 1998), leadership (Smith and Sorbets, 2003), and political culture (Cefaï, 2001) are now applied to territorial contexts. Neo-Marxist perspectives of "power structures" (Hunter, 1953), "growth coalitions" (Logan and Molotoch, 1987) and "post-Fordism" (Harvey, 1992; Jessop, 1994) have certainly been applied to local realities for a long time. Now, however, analysis has evolved towards illustrating "urban regimes" (Stone, 1989), public-private partnerships (Lorrain, 1995), "strategic" planning and management (Demesteere and Padioleau, 1992; Healey et al., 1997; Bouinot and Bermills, 1995), "projects" (Ingallina, 2001; Pinson, 2005), "governance" (Harding, 1993; Jouve and Lefèvbre, 1995; Stoker, 1999; Leresche, 2001) and actor networks (Novarina, 1997), among other topics, in the urban context. Studies refer to social capital and political capacity in the regions (Putnam, 1993; Pasquier, 2004), and offer interpretations of the new regionalism in Europe (Keating, 1998) as well as parameters for organisational innovation at the regional level (Cooke, 1997). Lastly, they refer to "collective actors" and to the interplay of identities, interests and organisations in territories, highlighting new possibilities for the common good (Ascher and Godard, 1999), about to be reborn as a "territorial construct" (Lascoumes and Le Bouhris, 1998).

Among this set of notions, let us consider that of "urban regime." Based on the systems of cooperation which, in certain cities, ${ }^{19}$ bring together actors from the economic and political arenas, cultural associations and universities, it points to the possibility of a coherent and "fair" governability in those complex worlds which are today's large cities. It speaks of collective action (i.e. "capacity to govern") in the territory, referring notably to the informal arrangements among very different categories of actors who are willing to negotiate and fashion common goals, as well as share their resources in order to accomplish them. This means that, in urban spaces, coalitions can be formed among diversified actors, devoted to partnerships and joint action. This gives cities political capacity and considerable governing autonomy. Beyond institutional, sectoral or personal cleavages, cooperation and trust systems arise, interconnecting very different partners. And if cooperation and loyalty must allow everyone to derive material and short-term benefits from the political "game," nonetheless they also point to lengthy processes of construction and learning as to the most 
desirable modalities of action, where collective problems are handled with shared norms and procedures, implying the development of a culture of compromise among the different segments of local forces.

Urban projects, adopted as unifying goals, can provide a fundamental impetus to this. ${ }^{20}$ And they illustrate the broader use now made of the notion of "project," it, too, with its "territorial" aspect - precisely that of the "project" as a gauge of the potentialities of collective action in territories. ${ }^{21}$

Calame and Talmant assert that, "in a society, the project is that which keeps people active. It is simultaneously a collective identity, the conviction that it is possible to escape impotence, that the passive experiencing of events is not inevitable, in sum, it is a desire for collective meaning" (1997: 119-120). The project occurs when "a human community becomes aware that what unites it is greater than what separates it," relying on the effects of culture and awareness of the public good which facilitate "the transformation of a dream into collective imaginary and then into strategy" (Calame and Talmant, 1997: 121). Besides, a project is not "the performing of pre-defined operations, but an investment in the collective ability to seize or engender opportunities. A project is the constitution of a collective intelligence. Ultimately, there is no project without mutual respect and friendship, because the project is the central element in an alliance. To make a project is to take part in an affective adventure" (ibid.: 121).

According to this view, projects are a means of creating unity of action in atomised systems, prompting forms of cooperation which would otherwise not occur. On the other hand, when "project" and "governance" are combined in territories, the assumption is that there is some capacity for self-government at the urban or regional level, bringing together forces and interests coming from distinct provenances. That is to say, one does not think so much in terms of "concrete action systems" (Friedberg, 1993) - which are more or less

\footnotetext{
${ }^{19}$ The case of Atlanta, described in Clarence Stone's work, is a case in point.

${ }^{20}$ Even if the gains obtained from projects benefit some more than others, favouring the economic elite (as proved by many analyses), the perception that lesser gains can nonetheless reach a large number of recipients is important for actors in the field.

${ }^{21}$ Territorial analysis partakes of that logic of the "project" with which we now assess ways of being and doing things. As Ehrenberg notes, "the notions of project, motivation and communication are now the norm. They have entered our customs and become a habit to which we, from the top to the bottom of the social hierarchy, have learned to adapt" (2000: 16). In the imperative of the project we find the mark of a time in which "the norm is no longer supported by guilt and discipline, but by responsibility and initiative [...] the individual is faced with a pathology of insufficiency, rather than with the pain of guilt, with a universe of malfunctioning, rather than with that of the law" (ibid.: 16).
} 
volatile, set up by outside action and kept in place simply for certain initiatives or goals - as in terms of a dynamic that is intrinsic to territories, that transmutes them into "collective actors" of some durability. Territories, then, appear as "contexts that have their own agenda, capacity for action and modes of regulation: territories that are capable of representing themselves as societies and collective actors acting in a context of territorial competition" (Pinson, 2002: 234). ${ }^{22}$

Projects may constitute a means for territories to put themselves forward to the outside world, based on the "specialised" skills which can be developed in them (Pinson and Vion, 2000). But, of equal or even greater importance, they organise collective action within their own universes. Testing the actual devolution of power to the territories, they express the capacity of each context to produce its own coalitions and solidarities - personal, institutional, reticular - around operating consensuses and shared visions as to territorial interests. In this sense, "project" implies processes of interaction that reduce uncertainty, enable learning and knowledge production, as well as collective decisions which constitute the territory as a community in action.

For this reason, actors' cooperation and legitimation in projects should not depend on or be centred around local institutions and politicians. The argument is that, in a real "project" dynamic, cooperation and mutual trust between participants emerge from a labour of densification of horizontal relations, producing identities and work teams which institute the territory as a sui generis political space. This occurs, naturally, in the sphere of public intervention, since it is the latter that provides the incentive for, and benefits from, the fact that the parties involved in "governance" feel the need to take "a view of the general interest that is accepted by others," accommodating the agreements established on the basis of projects or on "the definition of ends that are of common interest" (Marcou, 1997: 18). Above all, "projects" make an inventory of the relational, material and cognitive local resources, assessing the extent to which they are activated in the construction of structures for action based on interactions and on territorial identity. The ability to act collectively, which projects express, must also be met by particular modes of regulation, shared

\footnotetext{
22 Projects express themselves, for instance, in urban political operations that articulate a prospective and identity-based dimension with an operational dimension, in the shape of major urban and/or economic transformations that mobilise multiple actors and resources. They involve partnership methods, the successive negotiation of goals and ways of implementing them, as well as interaction between the different stages of the project (Pinson, 2004).
} 
representations of the future, challenges and controversies recognised as important, and a degree of cognitive harmonisation, endowing cities with the traits of a cultural and political system. This factor is all the more important as international competition between territories is in large measure decided according to the cohesion displayed by their systems of actors - in their ability to build new forms of bargaining, relations of trust and consensus transcending party, hierarchy or interest-based lines, bypassing politicised procedures in favour of broad-based social mobilisation rooted in civil society. Only thus can stability be brought to the cooperative game among the actors, leading them to discover common interests and feelings of belonging, to invest in dialogue and in interdependence, in reciprocity and common identity, territorialising their strategies, especially in economic terms. $^{23}$

"Governance" is then associated with this ideal type of "project of territory." It contributes towards debating the extent to which each city or region finds, in its representative bodies and figures, the means and the will - skills, material resources, operational instruments, mental predisposition, practical interest - to collectively assume modernising projects: urban regeneration, transport and mobility, environmental, scientific and other projects. Since what is required is that projects bring together multiple participants and serve a collective purpose, what is important is the fact that they can mobilise diversified networks and groups in territories, in an open and participated relational system (not imposed by the will of politicians), making the territory exist as a political subject, a territorial collective actor.

Finally, the notion of "common good as territorial construct" (Lascoumes and Le Bourhis, 1998 ) is all the more applicable as the differentiation of the stages on which public policies are played out appeals to modes of management that are less standardised and more specific to each place. The idea is that "discussion fora" in the territories may increasingly give rise to rules for framing agents and interventions in the field, creating joint-work habits that will lead to valid agreements on development and problem-solving. To speak of the "common good" as a territorial construct is to say that the interplay of identities, interests and oppositions in territories, very often resulting in competitive "jousts," can be resolved

\footnotetext{
${ }^{23}$ These are all aspects which the political establishment is in no condition to ensure, and it may even thwart them: "[T]he political establishment thus revises its role. It is no longer the main actor in the mediation and legitimation of actors. Instituting a territory involves, rather, processes of legitimation of interests and of social actors among themselves" (Pinson, 2002: 251).
} 
by mutual learning, favoured by interactions that lead to the adjusting of interests and to the reciprocal accommodation of the identities of those involved. Since interests and identities are not immutable, oppositions and clashes may represent an opportunity for interchange, teaching players how to deal, in a positive manner, with the initial antagonisms. What is important is that disagreements be subjected to procedures which can give rise to new perceptions of each actor's initial interests and positions, so that a sufficiently operational understanding of the general territorial interest can be reached. Thus, it is argued that conditions obtain in the territories to set up frameworks for adjusting competing identities and interests - even without formal devices or substantive goals determining interactions a priori - where the power of the State is reduced, at best, to "convening" the actors (Calame and Talmant, 1997; Ruivo, 2000b). ${ }^{24}$

The widespread conviction is that the technicist model which the political-administrative system grew accustomed to will be counterbalanced by a deliberatory model, characterised by the permanent adjusting of heterogeneous interests, the insertion of new actors in decision-making and the possibility of successively adapting, for a given territory, the goals agreed upon and the means to achieve them. That is to say, a model grounded in procedural policies defining interaction frames, where at each step the search for the common "territorial" interest is reactivated. What is essential is the setting up of territorial devices that ensure "organised interactions, modes of joint work, the formulation of collective agreements. Whereas classic public action presupposes the prior definition of the 'general interest', procedural action builds in stages a localised 'common good' that ensures the coherence and legitimacy of decisions" (Lascoumes and Le Bourhis, 1998: 40). ${ }^{25}$ Institutionalising these new ways of doing politics will entail the valorising of the agreements reached, their use as references for the future and the possibility of "exporting" the common good thereby achieved to territories exhibiting similar problems.

In sum, such an understanding of the "local" presents it as a space for harmonisation, negotiation, projects, resulting in "a concept of territory as a political construct based on

\footnotetext{
${ }^{24}$ Problem-solving rules and principles will gain significance in a given context, irrespective of whether national or sectoral goals and criteria are adhered to.

${ }^{25}$ On one side, there is the pragmatism of declared purposes and the malleability of procedures, making the local particularities of problems a matter of priority, but open to their evolution over time; on the other, the democratic aspect of the free clash of interests and dialogue between opposing viewpoints, with "structures of cooperation on the definition of local issues, working methods and decisions to be made" (Lascoumes and Le Bourhis, 1998: 40).
} 
interactions" (Autès, 2001: 21). The territory, conceived as a "project territory" through the work of the actors who decide to do something in cooperation, will thus re-establish the essence of the political: building something in common. ${ }^{26}$

\section{Desires and realities}

The notions above run the risk of being merely a stereotyped and normative view of things, based on theoretical formulations and wishful thinking, rather than on analysis of actual political practice. There are indeed many studies that contradict the assumptions sketched out above, with ample reference to situations at the antipodes of what they postulate. Among other things, these studies are attentive to the weight of institutions and the resistance to change in each situation, both nationally and locally.

Let us consider, for instance, the ways in which the central government has reassessed and controlled local government in the United Kingdom over the past few decades. To impose private management on local authority services, central authorities in the UK demolished to a significant extent the conditions for local autonomy, dismantling even the notion of territorial public service (Le Galès, 2005). This proved to be, in fact, a process of power recentralisation, mediated by control instruments used by government agencies to impose the "new public management" to local governments, entangling them in a tight bureaucratic net. Going against the grain of any kind of negotiated "governance," these processes of supervision and technical auditing, incitement to competition and "value for money," the measurement of performances and the ranking of local councils, set up in the name of the "entrepreneurialisation" of the public sector, created enormous tension between local authorities and government. As a result, the UK continues to be one of the most centralised countries in Europe, where local authorities display great fragility. This occurred while the strategic priorities of the territories and the specific needs of the population were "left aside, in favour of competition to obtain the highest mark, a symbol of political and professional success" (Le Galès, 2005: 263).

In turn, the territorialisation of public action in France has been riddled with contradictions, at every turn mitigated by the "return of the State" and by corporative logics,

\footnotetext{
${ }^{26}$ Communication, interaction, negotiation between actors in political and social fields produce the territory as a legitimate category for public action. In this sense, notions such as proximity, efficacy, participation and citizenship are the new materials of a political world built around the local: "[G]overnance, contracts, projects have become the new instruments of a public action under reconstruction" (Autès, 2001: 22).
} 
as well as the personal control wielded by local elected officials over processes supposed to provide greater openness, participation, transparency and supra-municipal articulation of local policies. ${ }^{27}$ In a country where the general interest is still understood as being consubstantial with the action of the State, according to Mérieux (2005), "subsidiarity" remains the exception, and it is difficult to combine the common interest with handing over to actors other than the State the means to produce public action at local level. ${ }^{28}$ For example, contractualising policies between government and local authorities appear to many to be reviving centralisation and unequal power relations between the State and local government, representing yet another opportunity to impose the centre's conditions on local "partners." Under the guise of negotiations between parties on an equal footing, there is a return to old imbalances, with the national referents and interests still overriding local priorities and referents.

If this is the situation in France, in most European countries "contractual cooperation is equally dependent on traditional modes of State action" (Marcou, 1997: 37). According to Marcou, there is still a great lack of transparency in contractualisation practices between the French State and local authorities. Indeed, French mayors, retaining exclusive control of territorial representation in State structures, are still in a position to override municipal opposition and participatory experiments when public contracts are established.

As a result, the optimism of notions of "contractualisation" and "governance," always ready to praise the democratic bent of the new partnerships and articulations, is very often disclaimed by the fact that leaders (both elected and technical) find it easier to identify with the administrative, economic and professional elites than with the population (Biarez, 1999). Under the mantle of territorial governance, there is often to be found a decision-making structure where economic agents merely participate if material gain is considerable and their view of interests predominates, with popular and associations' demands being left to ever more dwindling and uncertain public resources. Where participatory policies are

\footnotetext{
${ }^{27}$ Lascoumes and Le Bourhis had already pointed to the obstacles to deliberatory practices inherent in the construction of a "common good" in the territory. Factors such as the perpetuation of exclusivist relations, limited to certain groups and networks, on the part of the local political class, intent on keeping its hold on power by means of occasional, case-by-case negotiations with local actors, to whom it does not provide the means or the political will with which to form general and collective agreements in the territory, are still very much a fact of life.

${ }^{28}$ The author notes that '"subsidiarity' continues to be considered in derogatory terms - a system of exceptions included in the legal apparatus itself - rather than in 'suppletive' terms, which would attest to the
} 
concerned, things are very often left undone, especially in large cities, favouring the major businesses and representative economic bodies (Chambers of Commerce and Industry, business confederations), rather than the associations or the population at large (Lefèvre, 2005).

This is undoubtedly yet another sphere where the historical weight of national cultures is decisive (Heinelt, 2002). Nothing in fact can ensure that a fair and judicious selection of participants, their mutual trust and understanding, or the change in notions of citizenship required by participatory dynamics will occur. Besides, many studies prove that traditional mediation organisations (political parties and trade unions, churches, lobbies) always find ways of framing debates and leading participatory processes. Popular strata, inhibited by multiple disadvantages, tend to remain absent, and the mobilisation of the middle classes usually occurs only to safeguard privileges and individual well-being. ${ }^{29}$. In the case of French cities, once again the procedures of participatory democracy appear, over time, to have consolidated the power of the usual representative figures (Caillosse, 1999), especially the mayors. The needs of political socialisation and of internalising the rules of the game set down by politicians, the asymmetries in information between social groups, the degree of expertise required for many debates, do not simply drive away those whose resources are weaker, but have reinforced local government leaders' capacity to co-opt civil society's "legitimate representatives." 30

For these reasons, it comes as no surprise to find, for the French context, accounts of the opacity, muddle, disarticulation between levels of intervention, monopolisation and personalisation of power, the undermining of participatory democracy and the depletion of deliberatory assemblies, contempt for transparency and the politicising of projects, the reinforcing of rural/urban asymmetries and the "return of the State," which decentralisation was able to trigger, protect or establish. Mabileau (1997) concludes that in no other

will of the State as to the opening up of a space of relative autonomy for the construction of a 'territorial common good"' (Mérieux, 2005: 29).

${ }^{29}$ An entire school of interpretation insists on "the limits of the phenomenon, the effects of legitimation of asymmetrical power structures that it induces, the collusion between elites and the clientelist cooptation that pervade it, the distortions that social inequalities cause even in participatory practices" (Bacqué et al., 2005: 16).

${ }^{30}$ This gave rise to veritable mediation and participation professionals (Jouve, 2005), a new kind of notable sacralised at local level by the cognitive and instrumental skills they manage to garner and which bring them into the orbit of local government. The creation of "Development Councils," in cities exceeding 50,000 inhabitants, by the Voynet law (no. 99-533 of 25 June 1999) played a part in this "confiscation of the public debate by local notables" (ibid.). 
democratic country is the monopolistic power of local authorities so entrenched as in France. The possibilities of accessing central power agencies and the rules of "contact democracy," coupled lately with communication and image strategies, as well as prerogatives regarding the coordination of the local institutions that have been created, have turned municipal leaders into major "game masters. ${ }^{131}$ Where Mény (1992) speaks of a "republic of fiefdoms," others see the contradictory effect of decentralisation and of the "perverting of local democracy" in a regime of new feudal lords, so entrenched in decentralised France (Hureaux, 2004).

This analysis may be applicable to other countries of the "South," should there be confirmation that local administration systems in Southern Europe have adhered very little to the new public management and remain faithful to more classic practices (John, 2001). We know that in Portugal advances in decentralisation have been weak. Regionalisation and the establishment of successful metropolitan institutions having failed, the periphery remains under the sway of the "paradigm of continuous and interminable centralisation" (Monteiro, 1996: 22). Nevertheless, similarities with the diagnosis presented above are undeniable. This is both because any attempt at organisation in territorial contexts is constrained by strict dependence on the centre (in political, administrative, strategic and financial terms), and because, in a democracy characterised by the concentration of power in the hands of local government leaders, links between the centre and the territories continue to be made through more personalised channels, and the influence of elected assemblies and of socially and politically heterogeneous groups is residual. Privilege is granted to the mayor's network of collaborators, and institutions or opinions of a more public nature are sidelined, if not infrequently alienated (Ruivo and Francisco, 1998/1999). Besides, in a social worlds dominated by personal forms of interaction, it is the longevity in office of local government officials which assures the forms of integration and continuity deemed necessary, rather than some "territorial" culture of managing projects or seeking

\footnotetext{
${ }^{31}$ With decentralisation, the "mayoral" model was reinforced, giving the chief executive "an unprecedented prominence, derived from the confusion of territorial authorities (he is simultaneously head of the administration and president of the council assembly) and from the general weakness of political parties at local level" (Nay, 2003: 213). The bureaucratisation of the major French local councils, and the fact that they are endowed with technical powers, paradoxically increases the "monarchisation" of local authorities, with elected assemblies being left with the role of echoing chambers: "The work of constructing a public agenda continues to be, in practice, controlled by the boss, who relies on [...] a rearguard composed of a few men and women united by political allegiance, closet secrets and strongly informal work rules" (ibid.).
} 
the common good based on multi-participated frameworks. ${ }^{32}$ Cooperation, "pertinent" mobilisation, structures of trust, "strategy" and local identity, in sum, the attributes of socalled "social capital," as well as current notions of "governance" and "project," have to be viewed as dependent on the attributes of certain leaders - namely those with privileged links with different State sectors or services - around whom relational networks are organised with a view to enjoying the opportunities offered by public policies. It will therefore make little sense to search, in local universes in Portugal, for the kind of institutional efficacy and strategic action which history, culture, the global economy or decentralisation have driven forward in other contexts, building relations of trust and collective action among different societal sectors.

In the case of Portugal, there is a considerable distance between local government elites, on one side, and the social structure and social partners in general, on the other. The result is that the mayor's job becomes closed in on itself and on the mayor's group of associates. In practice, as privileged interlocutors of the State, in a society in which European integration reinforced the dependence on frames of reference and consensus established by the State (Reis, 2004), ${ }^{33}$ the locally elected mayors are not only the cornerstone of "territorial governance," but also one of the main obstacles to its evolution.

It is thus unrealistic to believe that the well-known difficulties experienced by Portuguese society in the autonomous organisation of interests can be overcome at local level, without the State laying down the parameters for relevant action. The rule is the "relative absence of joint dynamics" (Mozzicafreddo et al., 1991: 146), correlative with a presumed culture of passivity on the part of local citizens vis-à-vis local politics (Rocha, 1989) and with the fact that the mayor's team is at the centre of the interests, rather than the strategies, ${ }^{34}$ that guide local development. This contributes to that peculiarity of Portuguese society designated by Boaventura de Sousa Santos (2003) as the "absence of a project," as it does to the "localist" drift of any attempt at supra-municipal, metropolitan or regional rationalising of the administrative machinery.

\footnotetext{
32 The position taken recently by the National Local Government Association with regard to the possibility of limiting the duration of local government mandates is a symptom of the important role played by political longevity in local officials' sway over local spaces.

${ }^{33}$ Access to EU funding crystallised old functional and relational situations of dependence, with EU policy-based modernisation emphasising the centrality of the State and its policies.
} 
Moreover, the difficulties faced by inter-municipal associations, which work merely on a basis of isolated agreements, under-ambitious goals and for party-political pressure ends (Portas, 1988: 64), reveal another facet of Portuguese society: strong socio-territorial segmentation (Medeiros, 1988). This implies that any form of metropolitan or regional association has to face principles of exclusion and opposition grounded in regional-cultural differences. Hence, segmentary socio-territorial differentiations (neighbourhood allegiances, local patriotism, social segregation inscribed in the differences of habitat) tend to superimpose themselves onto modalities of cooperation or association, producing regional spaces that are mere juxtapositions of ego-centred rationalities and personal electioneering. In these circumstances, to speak of a territorial culture or collective action consciousness is daring. Especially as the State, in centring political life in the districts - bodies having little territorial and socio-economic significance, but which are functional for political action helps to obstruct territorial rationality and to hypertrophy electoral-political rationality (Reis, 1998).

In sum, dominated by atomistic logics, with a frail history of joint work or notions of a shared destiny, local government perpetuates a worldview which consolidates fragmentation and individualistic competition in the territory, and the State has used this to reinforce its own centrality and to undermine aspirations for more advanced territorial organisation. This means that Portugal also displays a state-centred model of governance (Kohler-Koch and Eising, 1999), which, on the one hand, controls the integration of local government into public policies and, on the other, encourages the patrimonial, personalised and privatistic appropriation of authority in municipalities, obstructing advances in territorial governance proper. Furthermore, State centralisation and the self-enclosure of local elites, in a territorially fragmented and State-dependent society, is not underpinned by a grassroots "civic culture" (Almond and Verba, 1963; Putnam, 1993) which might make local leaders adhere to broader structures of solidarity. The co-involvement of public authorities, interests and heterogeneous social groups in territorial strategies, following logics of "project" or "common good," can only be viewed as remote.

\footnotetext{
${ }^{34}$ Local government exists in a "strategic vacuum" which makes it vulnerable to sundry pressures exerted by local entrepreneurs, and very often its ability to intervene in the economic sphere is curtailed (Mozzicafreddo et al., 1991: 112).
} 
Lastly, as for the "territorialising" changes brought about by European construction, here again the differences between each local-national context remain fundamental, superimposed over any wishful considerations linked to the European variable (Boisseaux, 2005). That is to say, the opportunities provided by Europe to the territories have to be seen in the light of their specific institutional and relational configurations, which show different modes of functioning from country to country. Despite the "Euro-compatibility" ascribed to territorial institutions and agents, it is very often the case of "window-dressing Eurocompatibility" (ibid.). As noted by Mathiot (1998: 88), what frequently prevails is a kind of "European acculturation" that "seems less the constitution or fabrication of a new system of action than the incorporation into the existing system of 'what it takes to be European' in order to appear in Brussels as a reliable partner and thus likely to be helped" (ibid.: 88). Most of the time, EU policies consolidate the role of existing political-administrative networks, with no noteworthy forms of protest issuing from the territories.

Thus, "Europeanisation" is not only far from imposing a new constitutional situation on EU member States (Kohler-Koch, 1998: 53), but the result of its drive to empower territorial actors and enable them to intervene directly in public policies remains uncertain. Without underestimating the effects of Europeanisation on the principles and ways of governing at national level (Radaelli, 2001), we must be aware that the Commission shows no inclination, for instance, to interfere in the networks that organise public policy at this level, or to do anything which might in some way arouse mistrust within member States. All the more so since "it needs the states, and is more interested in policy effectiveness and efficient delivery than in broad issues of political restructuring" (Keating and Pintarits, 1998: 41). At best, EU guiding principles, practices and rules are an "offer" linked to financial transfers, i.e. modalities proposed to territorial agents regarding their relationship with the Commission, as well as concepts and strategies to improve competitiveness and the capacity for development of their spaces. However, this is merely "a window of opportunity, a supply that may or may not meet the demand of individual actors" (Kohler-Koch, 1998: 41). Only a detailed analysis will allow us to see to what extent the "ideological wrapping" with which the EU packs its programmes influences member States' institutional evolution, especially in what concerns greater territorialisation of policies and the enhancement of systems of territorial decision-making and public action. 


\section{Conclusion}

To deny the changes in ways of doing politics and of managing collective life brought about by the crisis of the State and the processes of its decentralisation, Europe building and globalisation, is to go against the evidence and, to some extent, assume that inertia is the rule in the social world. However, if concepts such as territorial "governance" or perspectives such as that of the territorialisation of public action, presented as a result of these factors, must be taken seriously, the ample transformation of the political practices such conceptualisations imply must be relativised. The reason for this is that the new consensus and ways of doing things that "governance" and "territories" will bring in their wake are far from assured. In territorial public action, everything still appears to be rooted in old foundations, as the ability or the will to escape old cognitive frames and outdated working methods appears to be lacking. Changes in scale cannot here be taken for changes in the substance of phenomena, as if the formats and norms of public action had made a clean break with the past. To conceive of territories (local, metropolitan, regional) as a revitalised source of collective action and a cradle of "strategic" coalitions - freed from State control, investing in the promotion of territorial identities, energised by "projects," "partnerships" or agendas ratified by citizens - means viewing reality still through the prism of desire. In the growing interdependency which today defines institutions and the management of public policies, there may be, no doubt, effects of "territoriality" with enough breadth to change the symbols, the beliefs, the narratives, the power relations and the operationality of public action. However, evidence shows that we should be cautious in the assessments we make.

The patterns of regulation and distribution of governments and national traditions are not gone. Besides, notwithstanding the popularity of notions such as that of "Welfare municipalities," the "local" does not replace citizenship (Schnapper, 1994b), nor has the localist, clientelist, individualistic culture of local government disappeared (Mény, 1994). On the other hand, professional groups and the interests of economic agents do not easily adjust to the demands of coherence, transversality and territorial identity, favouring rather their own "extra-territorial" logics of action. In fact, territorial strategic action is strongly mitigated by the difficulties of building lasting alignments in territories, given the discontinuities, the incongruence, dissonance, and specific temporalities of the projects of individuals, organisations and public policies. 
Hence, without overlooking institutional mimesis and the sense of good practice which result from the values of proximity, the partnerships and synergies with civil society, identities, governance, consensus and pragmatism, transparency and participation - among other references which confer primacy on actors and territorial contexts - the unavoidable conclusion is that the networks involved in these logics still evince a pronounced tendency towards reproducing the "identical." That is to say, the "old" and the "new" exist side by side with no great hindrance; clientelism is not gone, nor have networks become more transparent by being localised. In other words, actors still rely, to a large extent, on the beliefs and ways of acting to which they grew accustomed. It will come as no surprise, then, to witness situations in which any trace of the "territorial" is at the same time the "State," or the State under another guise, as well as situations where territorial specificities are basically granted by certain socio-economic sectors.

Once again, all of this must be considered on the basis of empirical research, if we are to understand and account for what is at stake. At best, we can speak of a transition from a more centralised, hierarchical and technocratic paradigm to new methodologies forged in territories, which Europe, sustainable development, democracy, and citizenship seems to require. However, nothing can be taken for granted, the reality of facts tempering enthusiasm with its complex matrix of continuity and innovation.

Translated by Monica Varese

Revised by Teresa Tavares

\section{References}

Almond, Gabriel; Verba, Sidney (1963), The Civic Culture: Political Attitudes and Democracy in Five Nations. Princeton: Princeton UP.

Ascher, François; Godard, Francis (1999), "Vers une troisième solidarité," Esprit, 11, 168-189.

Autès, Michel (2001), "Les politiques publiques locales," Les Nouvelles Politiques locales Cahiers lillois d'économie et de sociologie. Paris: L'Harmattan, 7-23.

Bayart, Jean-François (1985), "L'énonciation du politique," Revue Française de Science Politique, 35(3), 343-373.

Benko, Georges; Lipietz, Alain (eds.) (1994), "As regiões ganhadoras," Distritos e redes - os novos paradigmas da geografia económica. Oeiras: Celta.

Bacqué, Marie-Hélène et al. (2005), “Éditorial," Espaces et Sociétés, 123(4), 9-19.

Biarez, Sylvie (1999), "Incertitudes et caractère composite des gouvernements locaux en Europe," in Richard Balme; Alain Faure; Albert Mabileau (eds.), Les Nouvelles Politiques Locales. Paris: Presses de Sciences Po, 39-56. 
Boisseaux, Stéphane (2005), "Introduction - Territoires incertains: l'Europe en filigrane," in Alain Faure; Anne-Cécille Douillet (eds.), L'action publique et la question territoriale. Grenoble: PUG.

Bouinot, Jean; Bermills, Bruno (1995), La gestion stratégique des villes: entre compétition et cooperation. Paris: Armand Colin.

Caillosse, Jacques (1999), "Éléments pour un bilan juridique de la démocratie locale en France," in Loïc Blondiaux et al. (eds.), La démocratie locale. Représentation, participation et espace public. Paris: PUF, 63-78.

Calame, Pierre; Talmant, André (1997), L'État au coeur. Le mécano de la gouvernance. Paris: Desclée de Brouwer.

Cefaï, Daniel (2001), Cultures politiques. Paris: PUF.

Chevallier, Jacques (1978), "Le modele centre/périphérie dans l'analyse politique," in Jacques Chevallier et al. (eds.), Centre, Périphérie, Territoire. Paris: PUF.

Cohen, Michael D.; March, James G.; Olsen, Johan. O. (1972), “A Garbage Can Model of Organizational Choice," Administrative Science Quarterly, 17(1), 1-25.

Cooke, Phil (1997), "Institutional Reflexibility and the Rise of the Region State," in Georges Benko; Ulf Strohmayer (eds.), Space \& Social Theory. London: Blackwell.

Demeestere, R; Padioleau, J.G (1992), "Les démarches stratégiques de planification des villes," Annales de la Recherche Urbaine, 51, 28-39.

Donzelot, Jacques; Estèbe, Philippe (1994), L'État animateur. Essai sur la politique de la ville, Paris: Ed. Esprit.

Dubet, François (2002), Le déclin de l'institution. Paris: Seuil.

Dupoirier, Elisabeth (ed.) (1998), Régions, la croisée des chemins. Perspectives françaises et enjeux européens. Paris: Presses de Sciences Po.

Duran, Patrice; Thoenig, Jean-Claude (1996), “L'État et la gestion publique territoriale," Revue Française de Science Politique, 46(4), 580-623.

Duran, Patrice (1999), Penser l'action publique. Paris: L.G.D.J.

Ehrenberg, Alain (2000), La fatigue d'être soi. Dépression et société. Paris: Odile Jacob.

Friedberg, Erhard (1993), Le pouvoir et la règle. Paris: Seuil.

Gaudin, Jean-Pierre (1995), "Politiques urbaines et négociations territoriales, quelle légitimité pour les réseaux de politiques publiques?" Revue Française de Science Politique, 45(1), 31-56.

Gaudin, Jean-Pierre (1999), Gouverner par contrat. L'action publique en question. Paris: Presses de Sciences Po.

Grémion, Pierre (1977), Le pouvoir périphérique: bureaucrates et notables dans le système politique français. Paris: Seuil.

Hall, Peter A.; Taylor, Rosemary C.R. (1997), "La science politique et les trois néoinstitutionnalismes," Revue Française de Science Politique, 47(3-4), 469-496. 
Harding, Alan (1993), “'Gouvernance locale' et réaménagement urbain: pour un programme d'analyse comparative," in Sylvie Biarez; Jean-Yves Nevers (eds.), Gouvernement local et politiques urbaines. Actes du Colloque International, Grenoble 2-3 février. Grenoble: Ed. CERAT, 475-494.

Harvey, David (1992), "Social Justice, Postmodernism and the City," International Journal of Urban and Regional Research, 16, 588-601.

Healey, Patsy et al. (eds.) (1997), Making Strategic Spatial Plans. Innovations in Europe. London: UCL.

Heinelt, Hubert (2002), "Achieving Sustainable and Innovative Policies through Participatory Governance in a Multi-level Context," in Hubert Heinelt et al. (eds.), Participatory Governance in Multi-level Context. Concepts and Experience. Opladen: Leske+Budrich, 17-32.

Hunter, Floyd (1953), Community Power Structure. A Study of Decision Makers. Chapell Hill: University of North Carolina Press.

Hureaux, Roland (2004), Les nouveaux féodaux. Le contresens de la décentralisation. Paris: Gallimard.

Ingallina, Patrizia (2001), Le projet urbain. Paris: PUF.

Inglehart, Ronald (1993), La transition culturelle dans les sociétés industrielles avancées. Paris: Economica.

Jeffery, Charlie (ed.) (1997), The Regional Dimension of the European Union: Towards a Third Level in Europe? London: Frank Cass.

Jessop, Bob (1994), "The Regulation Approach, Governance and Post-Fordism: Alternative Perspectives on Economic and Political Change?" in Ash Amin (ed.), Post-Fordism. A Reader. Oxford: Blackwell.

John, Peter (2001), Local Governance in Western Europe. London: Sage.

Jouve, Bernard (1995), "Réseaux et communautés de politique publique en action," in Patrick Le Galès; Mark Thatcher (eds.), Les réseaux de politique publique. Débat autour des policy networks. Paris: L'Harmattan, 121-139.

Jouve, Bernard; Lefèvre, Christian (1999), "De la gouvernance urbaine au gouvernement des villes? Permanence ou recomposition des cadres de l'action publique en Europe," Revue Française de Science Politique, 49(6), 835-853.

Jouve, Bernard (2005), "La démocratie en métropoles: gouvernance, participation et citoyenneté," Revue Française de Science Politique, 55(2), 317-337.

Keating, Michael (1998), The New Regionalism in Western Europe. Aldershot: Edward Elgar.

Keating, Michael; Pintarits, Sylvia (1998), "Europe and the Regions: Past, Present, and Future," Comparative Social Research, 17, 33-63.

Kohler-Koch, Beate (1998), "La renaissance de la dimension territoriale en Europe: entre illusion et réalité, in Emmanuel Négrier; Bernard Jouve (eds.), Que gouvernent les régions d'Europe? Échanges politiques et mobilisations régionales. Paris: L'Harmattan. 
Kohler-Koch, Beate; Eising, Rainer (1999), The Transformation of Governance in the European Union. London: Routledge.

Klausen, Kurt K.; Goldsmith, Michael (eds.) (1997), European Integration and Local Government. Cheltenham: Edward Elgar.

Kooiman, Jan (ed.) (1993), Modern Governance. London: Sage.

Lacour, Claude (1996), "La tectonique des territoires: d'une métaphore à une théorisation," in Bernard Pecqueur (ed.), Dynamiques territoriales et mutations économiques. Paris: L'Harmattan, 25-48.

Lascoumes, Pierre; Le Bourhis, Jean-Pierre (1998), "Le bien commun comme construit territorial. Identités d'action et procédures," Politix, 42, 37-66.

Lascoumes, Pierre; Le Galès, Patrick (eds.) (2005), Gouverner par les instruments. Paris: Presses de Sciences Po.

Le Galès, Patrick (1998), "Régulation, gouvernance et territoire," in Jacques Commaille; Bruno Jobert (eds.), Les Métamorphoses de la Régulation Politique. Paris: L.G.D.J., 203240.

Le Galès, Patrick (2005), "Contrôle et surveillance. La restructuration de l'État en GrandeBretagne," in Pierre Lascoumes; Patrick Le Galès (eds.), Gouverner par les instruments. Paris: Presses de Sciences Po, 237-267.

Leca, Jean (1994), “L’Etat creux," in La France au-delà du siècle. Paris: L'Aube, 91-103.

Lefevbre, Rémi (2001), "Rhétorique de la proximité et 'crise de la représentation'," in Les nouvelles politiques locales - Cahiers lillois d'économie et de sociologie. Paris: L'Harmattan, 111-132.

Lefèvre, Christian (2005), "Faire des métropoles des territoires démocratiques", Pouvoirs Locaux, 65.

Leresche, Jean-Philippe (ed.) (2001), Gouvernance locale, coopération et légitimité. Le cas suisse dans une perspective comparée. Paris: Pedone.

Lindblom, Charles E. (1959), "The Science of Muddling Through," Public Administration Review, XIX, 79-88.

Logan, John; Molotoch, Harvey (1987), Urban Fortunes. The Political Economy of Space. Berkeley: University of California Press.

Lorrain, Dominique (1995), "Introduction - l'extension du marché," in Dominique Lorrain; Gerry Stoker (eds.), La privatisation des services urbains en Europe. Paris: La Découverte, 9-30.

Lorrain, Dominique (2000), "Gouverner les villes. Questions pour an agenda de recherche," Pôle Sud, 13, 27-40.

Lorrain, Dominique (2005), "Les pilotes invisibles de l'action publique, le désarroi du politique?" in Pierre Lascomes; Patrick Le Galès (eds.), Gouverner par les instruments. Paris: Presses de Sciences Po, 163-195.

Luhmann, Niklas; Schmutz; Jacob (1999), Politique et complexité. Paris: Cerf. 
Mabileau, Albert (1997), "Les génies invisibles du local. Faux-semblants et dynamiques de la décentralisation," Revue Française de Science Politique, 47(3-4), 340-376.

Marcou, Gérard; Rangeon, François; Thiébault, Jean-Louis (1997), La coopération contractuelle et le gouvernement des villes. Paris: L'Harmattan.

Marcou, Gérard (1997), “Introduction,” in Marcou et al. (1997), 7-41.

Massardier, Gilles (2003), Politiques et action publique. Paris: Armand Colin.

Mathiot, Pierre (1998), "Les effets de la gestion de dispositifs communautaires sur les acteurs et les systèmes d'action nationaux. L'exemple de l'Objectif 3 du Fonds Social Européen," Politix, 43, 79-91.

Mayntz, Renate (1993), "Government Failures and the Problem of Governability: Some Comments on a Theoretical Paradigm," in Jan Kooiman (ed.), Modern Governance. London: Sage, 9-20.

Medeiros, Fernando (1988), "Um sistema social de espaços múltiplos - a autonomia do local na sociedade portuguesa," Revista Crítica de Ciências Sociais, 25/26, 143-162.

Mény, Yves, (1992), "La république des fiefs," Pouvoirs, 60.

Mény, Yves (1994), "L'indispensable mutation des politiques territoriales," in La France audelà du siècle. Paris: L'Aube, 137-144.

Mérieux, Olivier (2005) "Introduction - Le débordement territorial des politiques sectorielles," in Alain Faure; Anne-Cécille Douillet (eds.), l'action publique et la question territoriale. Grenoble: PUG, 27-32.

Monteiro, Nuno Gonçalo (1996), "Os poderes locais no Antigo Regime", in César de Oliveira (ed.), História dos municípios e do poder local. Dos finais da Idade Média à União Europeia. Lisboa: Círculo de Leitores, 17-175.

Mozzicafreddo, Juan et al., (1991), Gestão e legitimidade no sistema político local. Lisboa: Escher.

Nay, Olivier (2003), "La politique des bons offices. L'élu, l'action publique et le territoire," in Jacques Jacques (ed.), La politisation. Paris: Belin, 199-219.

Négrier, Emmanuel; Jouve, Bernard (eds.) (1998), Que gouvernent les régions d'Europe? Échanges politiques et mobilisations régionales. Paris: L'Harmattan.

Novarina, Gilles (1997), "Les réseaux de politique urbaine. Concurrences et coopérations entre acteurs," in François Godard (ed.), Le gouvernement des villes. Territoire et pouvoir. Paris: Descartes \& Cie, 213-254.

Papadopoulos, Yannis (1995), Complexité sociale et politiques publiques. Paris: Montchrestien.

Pasquier, Romain (2004), La capacité politique des régions. Une comparaison France/Espagne. Rennes: PUR.

Pecqueur, Bernard (2000), Le développement local. Paris: Syros.

Pickvance, Chris; Préteicelle, Edmond (eds.) (1991), State Restructuring and Local Power. London: Pinter. 
Pinson, Gilles; Vion, Antoine (2000), "L'internationalisation des villes comme objet d'expertise," Pôle Sud, 13, 85-102.

Pinson, Gilles (2002), "Des villes et des projets. Changement dans l'action publique et institutionnalisation de nouveaux territoires politiques," in Joseph Fontaine; Patrick Hassenteufel (eds.), To Change or Not to Change. Les changements de l'action publique à l'épreuve du terrain. Rennes: PUR, 233-254.

Pinson, Gilles (2005), "Le projet urbain comme instrument d'action publique", in Lascoumes, Pierre; Le Galès, Patrick (eds.), Gouverner par les instruments. Paris: Presses de Sciences Po, 199-233.

Poggi, Gianfranco (1996), “La nature changeante de l'État. L'État et quelques aspects de son histoire," in Vincent Wright; Sabino Cassese (eds.), La récomposition de l'État en Europe. Paris: La Découverte, 19-35.

Pongy, Mireille (1997), "Gouvernance et citoyenneté, la différenciation du politique," in Guy Saez et al. (eds.), Gouvernance métropolitaine et transfrontalière. Paris: L'Harmattan.

Portas, Nuno (1988), "Sobre alguns problemas da descentralização," Revista Crítica de Ciências Sociais, 25/26, 61-78.

Putnam, Robert D. (1993), Making Democracy Work. Civic Traditions in Modern Italy. Princeton: Princeton UP.

Radaelli, Claudio M. (2001), "The Domestic Impact of European Union Public Policy: Notes on Concepts, Methods, and the Challenge of Empirical Research," Politique Européenne, 5(3), 107-142.

Reis, José (1998), “O que é o território?” Expresso, Fevereiro.

Reis, José (2004), “Estado, mercado e comunidade," Revista Crítica de Ciências Sociais, 70, 81-100.

Reis, José (2006), "Uma epistemologia do território," in Ensaios de Homenagem a António Simões Lopes. Lisboa: Instituto Superior de Economia e Gestão, 353-366.

Rhodes, R. A. W. (1997), Understanding Governance. Policy Networks, Governance, Reflexibility and Accountability. Buckingham: Open University Press.

Rocha, J. A. Oliveira (1989) "Governo local e cultura política: o caso da Póvoa do Lanhoso," Sociedade e Território, 9, 108-112.

Rouban, Luc (1999), "Introduction - Citizens and the New Governance," in Luc Rouban (ed.), Citizens and the New Governance. Beyond New Public Management. Ohmsha: IOS Press, $1-5$.

Ruivo, Fernando (1993), "Estado e poder relacional: a intervenção informal dos poderes locais em Portugal", in Boaventura de Sousa Santos (ed.), Portugal: Um retrato singular. Porto: Afrontamento.

Ruivo, Fernando (2000a), O Estado Labiríntico. O poder relacional entre poderes local e central em Portugal. Porto: Afrontamento.

Ruivo, Fernando (2000b), Poder local e exclusão social. Coimbra: Quarteto. 
Ruivo; Fernando; Francisco, Daniel (1998/1999), "O poder local entre centro e periferias," Revista Crítica de Ciências Sociais, 52/53, 281-306.

Saez, Guy (1997), "Les politiques publiques comme systèmes de coopération. Une lecture de l'approche conventionnaliste à travers H.S. Becker (et quelques autres...)," in Jean-Pierre Gaudin; Gilles Novarina (eds.), Politiques publiques et négociation. Multipolarités, flexibilités, hiérarchies. Quelques courants contemporains de recherche. Paris: CNRS Éditions, 19-43.

Santos, Boaventura de Sousa (2003), “Bloqueio em Movimento?” Visão, 8 May.

Santos, Boaventura de Sousa (2005), "A crítica da governação neoliberal: O Fórum Social Mundial como política e legalidade cosmopolita subalterna", Revista Crítica de Ciências Sociais, 72, 7-44.

Schnapper, Dominique (1994a), La communauté des citoyens. Sur l'idée moderne de nation. Paris: Gallimard.

Schnapper, Dominique (1994b), "Le local ne remplace pas la citoyenneté," in La France audelà du Siècle. Paris: L'Aube, 177-185.

Smith, Andy; Sorbets, Claude (eds.) (2003), Le leadership politique et le territoire. Les cadres d'analyse en débat. Rennes: PUR.

Stoker, Gerry (1998), "Cinq propositions pour une théorie de la gouvernance," Revue Internationale des Sciences Sociales, 155, 19-30.

Stoker, Gerry (ed.) (1999), The New Management of British Local Governance. Basingstoke: Macmillan.

Stone, Clarence S. (1989), Regime Politics: Governing Atlanta (1946-1988). Lawrence: Kansas UP.

Streeck, Wolfgang; Schmitter, Phillipe C. (eds.), Private Interest Government. London: Sage.

Timsit, Gérard (2004), "Critique de la gestion pure: la gestion du changement dans le secteur public des pays d'Europe Occidentale," Revue Internationale de Politique Comparée, II(2): 293-309.

Veltz, Pierre (2002), Des lieux et des liens. Politique du territoire à l'heure de la mondialisation. Paris: Ed. de l'Aube. 